УДК 342.9

DOI https://doi.org/10.32844/2618-1258.2019.3-1.25

IBAHOB O.B.

\title{
АДМІНІСТРАТИВНО-ПРАВОВІ ЗАСАДИ ДІЯЛЬНОСТІ СУБ'ЄКТІВ ЗАПОБІГАННЯ КОРУПЦІЇ У ЗАРУБІЖНИХ КРАЇН
}

У статті вивчено сучасні організаційно-правові форми роботи зарубіжних антикорупційних структур, їх нормативну основу, напрями реалізації поставлених завдань, механізми міжвідомчої взаємодії. Акцентовано увагу на діяльності антикорупційних органів таких європейських країн як Франція, Німеччина, Польща, Австрія та Сербія. Здійснено порівняння ефективності їх функціонування та запропоновано новели до імплементації в національний антикорупційний механізм. 3'ясовано, що Французьке антикорупційне агентство об'єднує три основні функції у державній протидії корупції, а саме: превентивну, контрольну та охоронну. Такий підхід $є$ позитивним та сприяє цілісності та послідовності процесу вирішення програмних антикорупційних завдань, оптимізуючи здійснення повноважень єдиним державним органом. Проте, негативною відмінністю від національної системи $є$ дуальна підпорядкованість Французького антикорупційного агентства відповідальним міністерствам, що значно девальвує як безпосередньо особливий адміністративно-правовий статус зазначеного суб'єкта, так і знижує рівень підконтрольності його діяльності.

Наголошено на підпорядкуванні Федерального Відомства Міністерству внутрішніх справ, що підтверджує європейську тенденцію функціонування антикорупційних установ в системі правоохоронних органів, зважаючи на покладені на нього завдання. Останні складають основу роботи відомства, а саме характерну йому чотирьохкомпонентну модель. Визначено, що трансформація підвідомчості НАЗК необхідна для вибудовування послідовного інституційного механізму боротьби з корупцією в Україні, удосконалення аспектів контролю та нагляду за діяльністю НАЗК, а також підвищення якості міжвідомчої комунікації та взаємодії з метою урахування цілого комплексу різноманітних аспектів реалізації антикорупційної політики.

Зроблено висновок, про доцільність зміни підвідомчості державного органу боротьби з корупцією., формування Антикорупційної стратегії за участі представників галузевих відомств виконавчої влади, консультаційна специфіка відбору кандидатури керівника органу запобігання корупції, створення окремого координаційного органу, інституційне залучення фахівців до державних заходів протидії корупції.

Ключові слова: антикорупчійний орган, зарубіжний досвід, нормативноправова основа, механізм взаємодії, імплементація.

At the article has been studied modern organizational and legal forms of functioning of foreign anti-corruption structures, its normative basis, directions of realization of the set tasks, mechanisms of interagency cooperation. Emphasis has been placed on the activities of anti-corruption bodies of such European countries as France, Germany, Poland, Austria and Serbia. Comparison of the effectiveness of its functioning has been made and novelties have been proposed for implementation in the national anticorruption mechanism.

It is revealed that the French Anti-Corruption Agency combines three main functions in the state anti-corruption, namely, preventive, control and security. This approach is positive and promotes the integrity and consistency of the process of solving anticorruption program tasks, optimizing the exercise of authority by a single state body. However, a negative difference from the national system is the dual subordination of the French Anti-Corruption Agency to the responsible ministries, which significantly devalues both the specific administrative and legal status of the said entity and reduces

(C) IBAНОВ О.В. - аспірант кафедри поліцейського права (Національна академія внутрішніх справ) 
the level of control over its activity. Emphasis was placed on the subordination of the Federal Office to the Ministry of Internal Affairs, which confirms the European tendency of functioning of anti-corruption institutions in the system of law enforcement agencies, taking into account the tasks assigned to it.

The latter form the basis of the work of the department, namely its characteristic fourcomponent model. It has been determined that the transformation of NAPC accountability is necessary to build a consistent institutional mechanism for combating corruption in Ukraine, to improve the control and oversight aspects of NAPC activities, as well as to improve the quality of interagency communication and interaction in order to take into account the whole range of various aspects of anti-corruption policy implementation. The conclusion was made about the expediency of changing the accountability of the state anti-corruption body.

Forming an Anti-corruption strategy with the participation of representatives of sectoral agencies of the executive power, consultative specifics of the selection of the candidate for the head of the anti-corruption body, creation of a separate coordinating body, institutional involvement.

Key words: anticorruption body, foreign experience, regulatory framework, interaction mechanism, implementation.

Постановка проблеми. Сьогодні в ході євроінтеграційних процесів відбувається активна модернізація управлінської антикорупційної системи в Україні. Безпосередньо однією з ключових підстав створення організаційного фундаменту для антикорупційних інституцій стала ратифікація Конвенції Організації Об’єднаних Націй проти корупції від 18.10.2006 року. Статтею 6 Конвенції передбачено обов'язковість функціонування органу протидії корупційним проявам та забезпечення його належного функціонування зі сторони Держави-учасниці [5]. Міжнародна спільнота вказує на необхідність реалізації вищезазначеного положення в рамках національної правової системи. Доцільним у впровадженні оновленої системи антикорупційних органів щодо боротьби з корупцією в Україні та ефективність їх подальшої діяльності вбачається шляхом адаптації ключових адміністративно-правових засад провідних країн світу, де відповідні суб'єкти протидії та запобігання корупції функціонують тривалий час.

Аналіз останніх досліджень та публікацій. Питання правового регулювання та особливостей діяльності антикорупційних органів зарубіжних та, зокрема, європейських, країн були предметом вивчення багатьох вітчизняних науковців та дослідників. Серед них варто виокремити доробки В.Д. Андріанова, І.А. Григоренко, В.М. Драган, З.А. Загиней, О.В. Новікова, О.В. Шкуупая, О.Н. Ярмиша.

Постановка завдання. Метою статті є вивчення зарубіжного досвіду адміністративно-правового регулювання суб'єктів запобігання корупції та оцінка його ефективності для впровадження в національний антикорупційний механізм.

Виклад основного матеріалу дослідження. Аналізуючи зарубіжний досвід протидії корупції, для антикорупційної політики України особливо актуальним є дослідження системи антикорупційних суб'єктів Європейських країн. Адже підписання угоди про асоціацію стало поштовхом до подолання тотальних корупційних схем та забезпечення прозорості влади в країні.

Так, у Франції функцію національного адміністративного контролю виконує Французьке антикорупційне агентство, створене у 2016 році відповідно до Закону про прозорість, боротьбу 3 корупцією та модернізацію економічного життя [2]. Варто відзначити, що агентство є органом влади, що наділено превентивними та контрольними повноваженнями, а також $є$ відповідальним за виконання судових заходів. Тобто, його діяльність спрямована на уніфіковану протидію корупції на державному рівні [7].

Акцентовано увагу на дуальному характері вертикальної підпорядкованості та підзвітності французької служби Міністру юстиції та Міністру бюджету, на яких власне покладено завдання реалізації державної антикорупційної програми. Окрім цього, агентство раз на рік звітує про дотримання програми та виконання заходів протидії корупції Генеральному прокурору [1, с. 2].

Очільником Французького антикорупційного агентства $\epsilon$ призначений наказом Президента Франції позаієрархічний магістрат, який наділяється особливим статусом незалежності. Позаієрархічність магістрата полягає в його неналежності до правоохоронної або судової системи Франції. При цьому, характерний статус незалежності забороняє Директору агентства при 
здійсненні контрольних місій робити запит або отримувати відповідні інструкції до виконання від будь-якого урядового чи муніципального органу влади [1]. Автор вважає за доцільне імплементувати в національний механізм позитивний досвід наділення центральної посадової особи національного антикорупційного органу - НАЗК спеціальним статусом як додаткову гарантію його адміністративної автономності під час здійснення повноважень.

Формування Антикорупційної стратегії як базового вектору діяльності Французького антикорупційного агентства реалізується завдяки функціонуванню Стратегічної ради, яка координується безпосередньо Директором. Підкреслимо, в основі процесу створення стратегічної програми є міжвідомчий підхід, який полягає в залученні до розробки представників уряду зі сторони різних центральних органів виконавчої влади. Так, до складу Стратегічної Ради відповідно до їхньої фінансово-правової компетентності та досвіді у боротьбі з корупцією входять по два члени від міністра юстиції, міністра бюджету, міністра закордонних справ та міністра внутрішніх справ [3]. Безперечно, така міжвідомча взаємодія спрямована на об'єктивний підхід у формування загальнодержавної антикорупційної стратегії в частині ії результативності та моновекторності організації взаємодії антикорупційних суб'єктів.

Отож, Французьке антикорупційне агентство об'єднує три основні функції у державній протидії корупції, а саме: превентивну, контрольну та охоронну. На нашу думку, такий підхід $€$ позитивним та сприяє цілісності та послідовності процесу вирішення програмних антикорупційних завдань, оптимізуючи здійснення повноважень єдиним державним органом. Проте, негативною відмінністю від національної системи є дуальна підпорядкованість Французького антикорупційного агентства відповідальним міністерствам, що значно девальвує як безпосередньо особливий адміністративно-правовий статус зазначеного суб'єкта, так і знижує рівень підконтрольності його діяльності. Однак, вбачаємо доцільним за прикладом Франції залучення до створення стратегічної антикорупційної програми України міністерських представників в аспекті комплексного узагальнення галузевих проблем щодо боротьби з корупцією. Також, варто взяти до уваги, надання керуючій посадовій особі НАЗК сутнісно важливого під час виконання поставлених перед ним завдань статусу незалежності повноважень та одноосібності у прийнятті рішень, що, в свою чергу, є гарантією виключення корупційних зловживань всередині агентства.

Поряд ыз діяльністю антикорупційних суб'єктів Франції, вагоме значення відводиться дослідженню та виокремленню позитивного досвіду Федеративної республіки Німеччини. Німецька поліцейська організація складається з федеральних органів, а саме: Федеральної кримінальної поліції (Bundeskriminalamt - BKA) і Федеральної прикордонної поліції, а також на рівні федеральних земель 16 центральних відділів кримінальної поліції і місцевих відділів поліції.

Корупційні справи є предметом сфери Федерального відомства кримінальної поліції, яка була заснована в 1951 році як центральний федеральний орган, безпосередньо підпорядкований федеральному міністру внутрішніх справ. Розслідування та кримінальне переслідування корупційних проступків власне підпадають під компетенцію антикорупційних суб'єктів федеральних земель.

Безпосередньо у складі ВКА функціонує інституційна одиниця боротьби з корупцією, яка складається з 6 осіб, які повністю реалізують аналітичні та стратегічні аспекти роботи [13].

Перспективними у структурі Федерального відомства щодо запобігання корупції вважаємо систему Науково-консультаційних центрів, які реалізовують наукове дослідження, зокрема кіберзлочинності, організованої та економічної злочинності, запобіганню корупційним правопорушенням тощо. Діяльність Науково-консультаційних центрів у визначених напрямах є достатньо ефективною та впливає на ефективність функціонування антикорупційних суб'єктів Німеччини. У зв'язку з цим впровадження Науково-консультативного центу з міжвідомчим підпорядкуванням та замовленням тематики наукових досліджень від Національного антикорупційного бюро, Антикорупційної прокуратури та НАЗК дасть позитивні результати в частині попередження та виявлення корупційних правопорушень. Створення Науково-консультативного центу $є$ основою для реалізації інформаційно-аналітичних функцій антикорупційних суб'єктів, а отже є перспективним до впровадження в Україні.

Разом $з$ тим, окрім внутрішньо інституційних аспектів функціонування відомства варто зазначити про реалізацію повноважень ВКА у процесі протидії корупції як складової національних об'єднаних платформ у боротьбі зі злочинністю. В українському варіанті, така міжвідомча співпраця мала би бути прерогативою Національного антикорупційного бюро України як головного суб'єкта у боротьбі з корупційними злочинами. Питання запобігання та протидії корупції базується перш за все на практиці її розслідування. 3 метою встановлення комплексної аналітико- 
стратегічної картини стану корупції в Україні, пропонуємо залучати до активної міжвідомчої співпраці з НАЗК у форматі об'єднаних інформаційних центрів та/або цільових груп, також інші органи виконавчої влади (міністерства, служби, агенції).

Таким чином, у Німеччині відсутній центральний орган виконавчої влади у сфері запобігання та боротьби з корупцією. Проте, при такій розгалуженості координація дій, з метою подолання та потенційного уникнення корупції, реалізовується ефективна міжвідомча співпраця декількох інституційних ланок в системі органів внутрішніх справ. Децентралізований характер обумовлений насамперед федеративним устроєм Німеччини, тож в контексті імплементації такий підхід у сучасній правовій реальності України не є зовсім доречним. Однак, впровадження такого формату управлінської взаємодії як спільні платформи комунікації за цільовим спрямуванням $є$ потенційно ефективним напрямком у якісній превентивній антикорупційній роботі НАЗК.

У Польщі функціонує Центральне антикорупційне бюро, на яке покладаються задачі ідентифікації, попередження, а також викриття корупційних дій та притягнення винних до відповідальності.

Значиму роль у діяльності бюро відіграє профілактична діяльність та відповідно аналітичні заходи, що їй передують. Аналітико-інформаційна звітність в межах компетенції антикорупційного органу здійснюється шляхом надання відповідної інформації Прем'єр-міністру, Президенту Республіки Польща, Сейму та Сенату. Тож, можемо відмітити повний відомчий моніторинг корупційної ситуації в країні з метою оперативного реагування на факти виявлення правопорушення [14].

Разом з тим, аналітика динаміки стану корупції у Польщі фіксується у щорічному звітному документі, що готується Центральним антикорупційними бюро та видається під назвою «Карта корупції». Цей звіт готується при взаємодії з іншими службами виконавчої влади, Генеральним прокурором і Міністерством юстиції [4].

Відповідно до статті 12 Закону про Центральне антикорупційне бюро, Голова подає не пізніше ніж за 2 місяці до закінчення календарного року голові Ради Міністрів на затвердження річний план дій бюро на наступний рік. В межах плану щорічно трансформуються форми та напрямки діяльності бюро в залежності від встановленої корупційної ситуації в країні. Вважаємо, необхідним адаптувати таку техніку стратегічного планування у роботі НАЗК.

Таким чином, профілактичну функцію у роботі національного антикорупційного суб'єкта варто звернути увагу на аналітичну діяльність Центрального антикорупційного бюро Польщі в частині організаційно-правового затвердження процедури подачі звітності по встановленим Антикорупційною стратегією напрямкам роботи. У зв'язку з цим, вважаємо, що звітність діяльності НАЗК повинна мати чітко визначену процедуру іiї подачі з визначенням звітного періоду впровадження положень стратегії. Тобто той чи інший аспект втілення антикорупційної новели до національного механізму матиме чіткий дедлайн. Такий механізм реалізації положень Антикорупційної стратегії формуватиме поступовість реалізації загальнодержавного плану боротьби 3 корупцією. Подібним в організаційному аспекті до українського антикорупційного органу є Антикорупційне агентство Сербії. Його діяльність регулюється Актом про Антикорупційне агентство від 27.10.2008.

Відповідно до внутрішньої структури реалізовують функціональне призначення агентства Директор та Правління. При цьому, зауважимо, що достатньо широкий об'єм повноважень належить насамперед Правлінню, яке призначає та звільняє директора Агентства, приймає рішення про підвищення заробітної плати директора, приймає рішення щодо оскарження рішень директора, готує річний звіт про діяльність Агентства та ін. До того ж, Правління може, за пропозицією директора, створювати дорадчі або функціональні органи Агентства.

Розглядаючи кадрові питання щодо Правління, то схема призначення кандидатів є достатньо широкою в контексті владних структур, які реалізовують можливість подання кандидатур. В цілому склад колегіального суб'єкта формується з дев'яти осіб. Члени Правління обираються Національною асамблеєю після подання кандидатури Адміністративного комітету Національної Асамблеї, Президента Республіки, уряду, Верховного касаційного суду, Державної контрольно-ревізійної установи, Захисника громадян та Уповноваженого з питань громадської важливості за спільною згодою, Соціально-економічної ради, Асоціації адвокатів Сербії та Асоціації журналістів Республіки Сербія за взаємною угодою. В той час як в Україні добір кандидатів здійснює Кабінет Міністрів України. Окрім цього, варто звернути увагу, що участь у пропозиціях на призначення беруть і представники громадськості. На нашу думку, такий підхід до формування персонального складу Правління Антикорупційного агентства дасть можливість створити реально 
незалежний автономний у власних діях суб'єкт запобігання та протидії корупції в країні. На підставі представленої аргументації відмітимо доцільність імплементації даної новели в національний механізм [12].

Таким чином, сербський антикорупційний орган за функціональним призначенням один 3 небагатьох, що збігається з діяльністю НАЗК. Організаційна структура втілює вищезазначену міжвідомчу взаємодії власне всередині самого антикорупційного органу. Скоординовані дії представників різних урядових та неурядових інституцій дадуть змогу приймати обгрунтовані, виважені та всебічно аргументовані рішення у діяльності НАЗК.

Поряд з вище зазначеним зарубіжним досвідом діяльності антикорупційних суб'єктів $\epsilon$ Австрія, де відповідальним за прогнозування, попередження та протидію корупції $є$ Федеральне Відомство 3 попередження та боротьби з корупцією. Відомство було створено в 2010 році в структурі Міністерства внутрішніх справ і наділене загальнонаціональною юрисдикцією [9]. 3 організаційної точки зору, Відомство прямо підпорядковане Міністру внутрішніх справ, адже структурно створене поза секцією Генерального Директорату з громадської безпеки, що є одним 3 координаційних департаментів більшості правоохоронних органів в Австрії. Австрійська установа протидії корупції тісно співпрацює з Державним прокурором у сфері протидії корупційним проступкам, які вчиняються посадовими особами [11, с. 5-6]. Первинна антикорупційна стратегія розробляється спільно Міністерством внутрішніх справ, Міністерством юстиції та Федеральним Відомством Австрії [8, с. 1].

У своїй діяльності австрійський антикорупційний орган дотримується 4-компонентної моделі, спрямованої на запобігання (аналіз корупційних явищ та розробку відповідних заходів профілактики), інформованість (шляхом розповсюдження інформації, освітніх заходів), протидію (розслідування кримінальних справ) та співпрацю з національними та міжнародними організаціями, що діють у сфері запобігання та боротьби з корупцією, а також обмін професійними практичними працівниками [10].

Окрім цього, Рішенням Ради Міністрів від 29 січня 2013 року федеральний уряд Австрії створив Координаційний комітет з питань боротьби з корупцією. Комітет збирається декілька разів на рік та складається з представників федерального канцлера, міністерств, Парламентської адміністрації, Європейської економічної палати Австрії, Федерального управління з попередження корупції та боротьбі з корупцією, Управління корупційної прокуратури, суду та ін. Координаційний комітет з питань боротьби 3 корупцією сприяє обміну інформацією 3 питань боротьби 3 корупцією в Австрії. До того ж, Координаційний комітет слугує інформаційним центром у межах свого мандату щодо реалізації національної антикорупційної стратегії [6, с. 2-3].

Увагу акцентовано на підпорядкуванні Федерального Відомства Міністерству внутрішніх справ, що підтверджує європейську тенденцію функціонування антикорупційних установ в системі правоохоронних органів, зважаючи на покладені на нього завдання. Останні складають основу роботи відомства, а саме характерну йому чотирьохкомпонентну модель. Необхідно вказати, що австрійський механізм відбору кандидата на посаду очільника антикорупційного органу $\epsilon$ специфічним як для інших зарубіжних країн, однак вбачаємо певну доцільність консультацій Президента $з$ представниками вищого правосуддя республіки. Безперечно створення та діяльність окремого координаційного органу для інформаційної взаємодії має сенс, що стосується, зокрема, питань виконання стратегічної програми або обміну значимими галузевими даними.

Висновки. Таким чином, трансформація підвідомчості НАЗК необхідна для вибудовування послідовного (покрокового) інституційного механізму боротьби з корупцією в Україні, удосконалення аспектів контролю та нагляду за діяльністю НАЗК, а також підвищення якості міжвідомчої комунікації та взаємодії з метою урахування цілого комплексу різноманітних аспектів реалізації антикорупційної політики.

1. Зміна підвідомчості державного органу боротьби з корупцією. Так, серед досліджених країн доволі часто антикорупційна структура $є$ елементом правоохоронної системи (Австрія) або ж характеризується дуальною підпорядкованістю декільком відповідальним міністерствам (Франція).

2. Формування Антикорупційної стратегії за участі представників галузевих відомств виконавчої влади. Створення базисного документа повинно здійснюватись 3 урахуванням специфіки вчинення корупційних проступків, недоліків впровадження попередніх антикорупційних стратегій, пропозицій недержавних інституцій, вітчизняних та зарубіжних експертів.

3. Консультаційна специфіка відбору кандидатури керівника органу запобігання корупції. За зразок взято австрійський механізм, де радниками виступають представники правосуддя. 
Варто вказати, що дорадчий колектив може бути представлений інакшим складом, позаяк необхідно зважати на компетенції потенційних консультантів.

4. Створення окремого координаційного органу. Дана форма міжвідомчої співпраці матиме результатом функціонування продуктивної платформи обміну інформацією стосовно виконання поставлених стратегічних завдань, проблемних питань, актуальних реформ та налагодження комунікації між суб'єктами антикорупційної дії.

5. Інституційне залучення фахівців до державних заходів протидії корупції. Цю ідею може бути використано з метою вирішення конкретних завдань, що виходять за межі юрисдикційної обізнаності працівників антикорупційного органу та виникають на території окремих регіонів країни, що мають власні особливості корупційних проявів, наприклад, у бізнес-сфері.

\section{Список використаних джерел:}

1. Загальна презентація Французького антикорупційного агентства від січня 2018. URL: https://www.economie.gouv.fr/files/files/directions_services/afa/AFA_Presentation_ Janvier.pdf.

2. Закон Франції про прозорість, боротьбу з корупцією та модернізацію економічного життя № 2016-1691 від 9.12.2016. URL: https://www.legifrance.gouv.fr/affichTexte.do?cidTexte=JORFT EXT000033558528\&categorieLien=id.

3. Інформайіна сторінка Стратегічної ради на Офіційному сайті Французького антикорупційного агентства. URL: https://www.economie.gouv.fr/afa/conseil-strategique.

4. Інформаційна сторінка Офіційного сайту Центрального антикорупційного бюро. URL: https://cba.gov.pl/pl/o-cba/zadania/350,zadania.html.

5. Конвенція Організації Об’єднаних Націй проти корупції від 31.10.2003. URL: https://zakon.rada.gov.ua/laws/show/995_c16.

6. Лекція в Раді Міністрів на тему «Національна антикорупційна стратегія Австрії». URL: https://www.bundeskanzleramt.gv.at/documents/131008/642767/6_21_mrv. pdf/6d5af947-26df-4d23-8aca-336a578131e1.

7. Наказ № 14- 2017 про Французьке антикорупційне агентство від 14 березня 2017 року. URL: https://www.legifrance.gouv.fr/affichTexte.do?cidTexte=JORFTEXT0000341876 $70 \&$ dateTexte $=\&$ categorieLien $=\mathrm{id}$.

8. Національна антикорупційна стратегія Австрії. URL: https://www.bmi.gv.at/510/files/ NAKS_Web.pdf.

9. Офіційний сайт Федерального Відомства з попередження та боротьби з корупцією Австріï. URL: https://www.bak.gv.at/.

10. Поправка до Закону Австрії про поліцейське співробітництво $\mathrm{CC}(\mathrm{EU}-\mathrm{PolKG})$ і щодо Федерального відомства з попередження та боротьби з корупцією (BAK-G). URL: https://www.ris. bka.gv.at/Dokumente/BgblAuth/BGBLA_2017_I_101/BGBLA_2017_I_101.html.

11. Річний звіт діяльності Федерального Відомства 3 попередження та боротьби з корупцією Австрії 2017. URL: https://www.bak.gv.at/Downloads/files/Jahresberichte/Jahresbericht_2017_ WEB_V2.pdf.

12. Anti-corruption agency act. Unofficial translation OSCE Mission to Serbia Amended August 2010. "Official Gazette of the RS", No. 97/08 from 27 October 2008. URL: https://www.osce.org/ serbia $/ 35100$ ?download $=$ true .

13. Organigramm des Bundeskriminalamtes (Stand 01.06.2019). Офіційний сайт BKA. URL: https://www.bka.de/SharedDocs/Downloads/DE/DasBKA/Organisation_Aufbau/organigramm_neu. pdf? _blob=publicationFile \&v $=19$.

14. Ustawa z dnia 9 czerwca 2006 r. o Centralnym Biurze Antykorupcyjnym. URL: https://bip.cba.gov.pl/ftp/prawo/ustawa_o_CBA_2017.pdf. 